\title{
Independent markers of congestion in patients with left ventricular systolic dysfunction
}

\section{Sol ventriküll sistolik disfonksiyonu olan hastalarda konjesyonun bağımsız belirteçleri}

\author{
Ömer Cağlar Yilmaz , Selçuk Özkan²
}

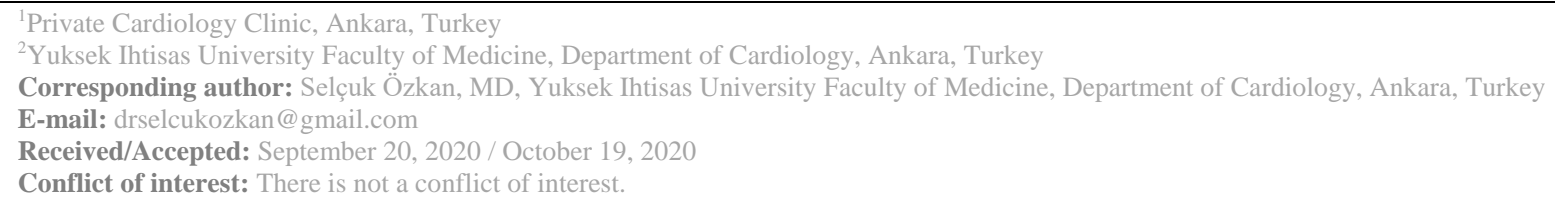

\section{SUMMARY}

Objective: Left ventricle systolic dysfunction is a serious cardiovascular condition that causes morbidity and mortality. Congestion is not a feature in every patient and the factors affecting congestion is not clearly defined. The aim of this study is to determine the factors causing congestion in elderly patients with left ventricle systolic dysfunction.

Method: Total number of 101 patients admitted to Cardiology and Internal Medicine outpatient clinics with left ventricle systolic dysfunction (ejection fraction $<40 \%$ ) were enrolled in the study. Cardiovascular risk factors, chronic obstructive lung disease and other systemic diseases of the patients were evaluated. Congestion was determined and graded according to their clinic.

Results: Mean age of the patients was $62,7 \pm 6,7$ and 54 (54\%) were male. Mean left ventricle ejection fraction was 31.1 \pm 5.8 . Multivariate regression analysis revealed that chronic obstructive lung disease $(\mathrm{t}=4,528, \mathrm{p}<0,001)$, left ventricle end diastolic diameter $(\mathrm{t}=3,149, \mathrm{p}=0,002)$, and atrial fibrillation $(t=2,137, p=0,035)$ were independent predictors of congestion. Conclusions: In elderly patients with left ventricle systolic dysfunction chronic obstructive lung disease, ventricle end diastolic diameter, and atrial fibrillation were found related to congestion. Evaluating and managing these factors in elderly patients with left ventricle systolic dysfunction might be important in preventing congestion.

Keywords: Hearth failure, congestion, atrial fibrillation



ORCID IDs of the authors: Ö.C..Y. 0000-0001-5245-5216 S.Ö. 0000-0003-3613-736X

\section{ÖZET}

Amaç: Sol ventrikül sistolik disfonksiyonu morbidite ve mortaliteye sebep olan ciddi bir kardiyovasküler durumdur. Konjesyon bu hastaların tamamında görülmemekte ve görülmesinin hangi faktörlere bağlı olduğu kesin olarak bilinmemektedir. Bu çalışmanın amacı sol ventrikül disfonksiyonu olan yaşlı hastalarda konjesyona neden olan faktörlerin tespit edilmesidir.

Yöntem: Kardiyoloji ve İç hastalıkları polikliniklerine başvuran, ekokardiyografisinde sol ventrikül disfonksiyonu olan (Ejeksiyon fraksiyonu<\%40) 101 hasta çalı̧̧maya dahil edildi. Hastalar kardiyovasküler risk faktörleri, kronik obstrüktif akciğer hastalığı ve diğer sistemik hastalıklar açısından tarandı. Klinik olarak konjesyon durumu belirlenip derecelendirildi.

Bulgular: Hastaların yaş ortalaması $62,7 \pm 6,7$ idi ve $54^{\prime}$ ü (\%54) erkekti. Hastaların ortalama sol ventrikül ejeksiyon fraksiyonu 31,1 $\pm 5,8$ idi. Multivariate regresyon analizi sonucunda kronik obstrüktif akciğer hastalığı varlığı ( $\mathrm{t}=4,528$, 
$\mathrm{p}<0,001)$, sol ventrikül diyastol sonu çapı $(t=3,149, \mathrm{p}=0,002)$ ve atriyal fibrilasyon varlığ $(\mathrm{t}=2,137, \mathrm{p}=0,035)$ konjesyon derecesini öngörmede bağımsız prediktörler olarak tespit edildi.

Sonuç: Sol ventrikül sistolik disfonksiyonu olan yaşlı hastalarda kronik obstrüktif akciğer hastalığı, sol ventrikül diyastol sonu çapı ve atrial fibrilasyon mevcudiyeti konjesyon ile ilişkili bulunmuştur. Sol ventrikül sistolik disfonksiyonu olan yaşlı hastaların bu faktörlerin vardığı açısında değerlendirilmesi ve takibi konjesyonun önlenebilmesi için önemli olabilir. Anahtar sözcükler: Kalp yetmezliği, konjesyon, atrial fibrilasyon

\section{INTRODUCTION}

Left ventricular systolic dysfunction is a serious cardiovascular condition with morbidity and mortality ${ }^{1}$. Congestion, which is one of the reasons for presenting patients with left ventricular dysfunction, is not seen in all of these patients and it is not known exactly which factors are related to its occurrence.

The clinical presentation of left ventricular systolic dysfunction can range from the asymptomatic stage to congestive heart failure ${ }^{2}$. It is important to determine the factors that lead to congestion and to control these factors, since congestive symptoms are effective in determining the stage of heart failure and cause complaints such as dyspnea, orthopnea, paroxysmal nocturnal dyspnea, edema, hepatomegaly and acid in patients, leading to impairment in quality of life.

The aim of this study is to determine the factors that cause congestion in elderly patients with left ventricular dysfunction.

\section{MATERIAL AND METHODS}

One hundred one patients who admitted to the cardiology and internal diseases outpatient clinics between 2014-2019 who had left ventricular dysfunction determinated with echocardiography were included in the study. After the history and physical examinations of the patients, biochemical examinations were performed. Patients were screened for cardiovascular risk factors, chronic obstructive pulmonary disease and other systemic diseases. Patients who received diuretic therapy in the last 2 weeks were excluded from the study because it would affect the congestion status.

Transthoracic echocardiography was performed to all patients. A 12-lead ECG was taken while resting. Patients with left ventricular systolic dysfunction (Ejection fraction <40\%) on transthoracic echocardiography were included in the study.
Congestive findings such as peripheral edema, ascites, hepatomegaly, crepitant rale, orthopnea, paroxysmal nocturnal dyspnea were clinically detected in the patients. If none of these signs and symptoms were present, congestion was considered absent. Congestion was classified as mild if there was one finding, moderate if there were two, severe if there were three findings, and severe congestion if there were four or more findings.

\section{Transthoracic Echocardiography}

Transthoracic echocardiography system was performed on each patient using three (GE Vingmed Ultrasound, Horten, Norway) cardiac ultrasound scanners. End-diastolic diameter, endsystolic diameter and left ventricular ejection fraction were measured by echocardiography.

\section{Statistical analysis}

The data of the study were recorded in the SPSS 15.0 program and the data were checked by a second author. Categorical data were given as numbers and percentages, normally distributed numerical data as mean $\pm \mathrm{SD}$, non-normally distributed data as median (minimum-maximum). Pearson's test was used for correlation analysis. Logistic regression was used for multivariate analysis. A P $<0.05$ was considered significant. Statistical analysis of the data was done in SPSS 15.0 program.

\section{RESULTS}

The mean age of 101 patients evaluated was $72.7 \pm$ 6.7 and 54 (54\%) were male. The mean left ventricular ejection fraction of the patients was $31.1 \pm 5.8$. The general characteristics and echocardiography findings of the patients are shown in Table 1. Twenty-seven (27\%) patients had no signs of congestion, 28 (28\%) patients had mild congestion, $30(30 \%)$ patients had moderate, $10(10 \%)$ patients had severe, and $6(6 \%)$ patients had very severe congestion. 
Table 1: General characteristics and echocardiography findings of the patients

\begin{tabular}{|l|l|}
\hline & Patients $(\mathrm{n}=101)$ \\
\hline Age (Mean \pm SD year) & $72,7 \pm 6,7$ \\
Male/Female (n. - \%) & $54 / 47(54 / 46 \%)$ \\
Hypertension (n. - \%) & $69(\% 69)$ \\
Diabetes Mellitus (no. - \%) & $22(\% 22)$ \\
COPD (no. - \%) & $24(\% 24)$ \\
CAD (no. - \%) & $85(\% 85)$ \\
AF (no. - \%) & $14(\% 14)$ \\
& \\
Echocardiography & \\
LVEDD $(\mathrm{cm})$ & $6,4 \pm 0,5$ \\
LVESD (cm) & $5,2 \pm 0,6$ \\
LVEF $(\%)$ & $31,1 \pm 5,8$ \\
\hline
\end{tabular}

COPD: Chronic obstructive pulmonary disease

CAD: Coronary artery disease

AF: Atrial Fibrillation

LVEDD: Left ventricle end diastolic dimension

LVESD: Left ventricle end systolic dimension

LVEF: Left ventricle ejection fraction

Of the patients, 14 had atrial fibrillation, 22 had diabetes mellitus, 69 had hypertension, 85 patients had coronary artery disease, and 24 patients had chronic obstructive pulmonary disease.

The degree of congestion is weak with left ventricular end-diastolic diameter $(\mathrm{r}=0.337, \mathrm{p}=$ 0.001 ), left ventricular end systolic diameter is weak $(\mathrm{r}=0.336, \mathrm{p}=0.001)$, moderate with presence of atrial fibrillation $(r=0.480, p<0.001)$ was severely $(r=0.509, p<0.001)$ with the presence of chronic obstructive pulmonary disease.

In the multivariate regression analysis, the presence of chronic obstructive pulmonary disease $(\mathrm{t}=4.528, \mathrm{p}<0.001)$, left ventricular end diastolic diameter $(t=3.149, p=0.002)$ and the presence of atrial fibrillation $(\mathrm{t}=2.137, \mathrm{p}=0.035)$ predicted the degree of congestion. they were independent predictors.

\section{DISCUSSION}

In this study in which elderly patients with left ventricular dysfunction were evaluated, the factors affecting congestion were determined as chronic obstructive pulmonary disease, left ventricular enddiastolic diameter and atrial fibrillation. Since the factors that cause congestion in left ventricular dysfunction, especially in elderly patients, have not been clearly defined until now, the results of this study are important. It is possible to prevent congestion that causes serious morbidity and mortality by controlling those factors that can be evaluated and controlled in elderly patients with left ventricular dysfunction.

In this study, the most important factor affecting congestion was found to be concomitant chronic obstructive pulmonary disease. Right heart failure is common in patients with chronic obstructive pulmonary disease. Congestion develops in patients with chronic obstructive pulmonary disease due to impaired right ventricular functions ${ }^{3}$. Therefore, the incidence of congestion is higher in patients with chronic obstructive pulmonary disease compared to those with only left ventricular dysfunction.

In this study, atrial fibrillation was found among the independent factors affecting congestion. In atrial fibrillation, left ventricular filling and stroke volume are affected due to impaired left atrial function. When atrial fibrillation develops in patients with heart failure, the patients become decompensated and clinical pictures up to pulmonary edema occur ${ }^{2}$. Karayannis et al. Showed in their study that left atrial remodeling increased from asymptomatic left ventricular dysfunction to symptomatic heart failure ${ }^{4}$. These 
mechanisms can explain the reason for the finding detected in this study.

In our study, left ventricular end-diastolic diameter was also one of the independent predictors affecting congestion. Interestingly, no effect of left ventricular ejection fraction on congestion was found. Increasing the left ventricular end-diastolic diameter has a negative effect on left ventricular filling dynamics. Therefore, an increase in left atrial pressures, an increase in lung capillary wedge pressure, impairment in right ventricular functions and as a result of congestion occur in the media ${ }^{5}$.

One limitation of this study is that it is not a prospective study, and it is only at the hypothesis level to comment on whether congestion can be prevented by controlling these factors, which are found to be related to congestion. Further studies planned in a prospective order are needed to determine clearly whether congestion can be prevented by controlling these factors.

In conclusion, chronic obstructive pulmonary disease, left ventricular end diastolic diameter and presence of atrial fibrillation in elderly patients with left ventricular systolic dysfunction are associated with congestion. Evaluation and followup of elderly patients with left ventricular systolic dysfunction in terms of these factors may be important to prevent congestion.

\section{REFERENCES}

1. Chronic Heart Failure: ACC/AHA guideline. J Am Coll Cardiol 2005;46:1144-1178

2. ESC Guidelines for the diagnosis and treatment of acute and chronic heart failure 2008. European Heart Journal (2008) 29, 2388-2442

3. Braunwald E. heart failure. Braunwald Zipes Bonow, Libby. Heart disease: a textbook of cardiovascular medicine, 7th ed. Philadelphia W.B. Saunders; 2005. p. 457-641.

4. Karayannis G, Kitsios G, Kotidis H, Triposkiadis F. Left atrial remodelling contributes to the progression of asymptomatic left ventricular systolic dysfunction to chronic symptomatic heart failure. Heart Fail Rev. 2008 Feb;13(1):91-8.

5. Schwammenthal E, Popescu BA, Popescu AC, Di Segni E, Guetta V, Rath S, Eldar M, Feinberg MS.Association of left ventricular filling parameters assessed by pulsed wave Doppler and color M-mode Doppler echocardiography with left ventricular pathology, pulmonary congestion, and left ventricular end-diastolic pressure. Am J Cardiol. 2004 Aug 15;94(4):488-91. 